\title{
Biological traits of Quadrastichus mendeli (Hymenoptera, Eulophidae), parasitoid of the eucalyptus gall wasp Leptocybe invasa (Hymenoptera, Eulophidae) in Thailand
}

\author{
Benjakhun Sangtongpraow*, and Kosol Charernsom \\ Department of Entomology, Faculty of Agriculture, Kasetsart University, Bangkok 10900, Thailand
}

Received 23 July 2018, Accepted 11 February 2019, Published online 22 February 2019

\begin{abstract}
Quadrastichus mendeli Kim \& La Salle, a parasitoid of Leptocybe invasa Fisher \& La Salle, is a uniparental species. This study assessed the biological traits of $Q$. mendeli in the laboratory at a temperature of $27 \pm 1{ }^{\circ} \mathrm{C}$. Diets had a highly significant effect on the mean longevity of female $Q$. mendeli. Feeding honey solution prolonged the mean longevity of the parasitoid to 4.80 days. The estimated $50 \%$ survival period was 3 days. The mean potential fecundity in all ages was 8.85 eggs per female. Age had a highly significant effect on the mean egg load. There was a positive relationship between egg load and female size. The mean of realized fecundity throughout the life span was 2.47 progenies per female. The mean developmental time of $Q$. mendeli from the egg to adult stage was 27.06 days. The shorter developmental time of $Q$. mendeli in comparison to its host can be considered a reason for the successful control of L. invasa in Thailand.
\end{abstract}

Key words: Biological control, Parasitoid, Quadrastichus mendeli, Eucalyptus gall wasp, Leptocybe invasa, Hymenoptera.

\begin{abstract}
Résumé - Caractéristiques biologiques de Quadrastichus mendeli (Hymenoptera, Eulophidae), parasitö̈de de Leptocybe invasa (Hymenoptera, Eulophidae), l'agent de la galle de l'eucalyptus, en Thaïlande. Quadrastichus mendeli Kim \& La Salle, un parasitoïde de Leptocybe invasa Fisher \& La Salle, est une espèce uniparentale. Cette étude a évalué les traits biologiques de $Q$. mendeli en laboratoire à une température de $27 \pm 1{ }^{\circ} \mathrm{C}$. Les régimes ont un effet très significatif sur la longévité moyenne de $Q$. mendeli femelle. L'alimentation avec une solution de miel a prolongé la longévité moyenne du parasitoïde à 4,80 jours. Le temps de survie estimé à $50 \%$ était de 3 jours. La fécondité potentielle moyenne à tous les âges était de 8,85 œufs par femelle. L'âge avait un effet très significatif sur la charge moyenne en œufs. Il y avait une relation positive entre la charge en œufs et la taille de la femelle. La fécondité moyenne réalisée au cours de la vie était de 2,47 descendants par femelle. Le temps de développement moyen de $Q$. mendeli du stade œuf au stade adulte était de 27,06 jours. Le temps de développement de $Q$. mendeli, plus court que celui de son hôte, peut être considéré comme une raison du succès du contrôle de $L$. invasa en Thaïlande.
\end{abstract}

\section{Introduction}

Eucalyptus camaldulensis Dehnh. (Myrtales: Myrtaceae) is a major fast-growing hardwood tree species in Thailand, and it is used in the production of timber, pulp, bioenergy and other minor products. The cultivated areas under the cover of eucalyptus in Thailand are mainly in the east, north-east and west of the country, and their increase has given rise to eucalyptus insect pests [37]. The eucalyptus gall wasp, Leptocybe invasa Fisher \& La Salle, originates from Australia and has become a global pest in eucalyptus plantations [32]. Leptocybe invasa

\footnotetext{
*Corresponding author: fagrbks@ku. ac. th
}

has expanded to more than 39 countries in Asia, Africa, Europe and the Americas [36]. In Thailand, this eucalyptus gall inducer has established itself successfully in E. camaldulensis plantations for more than a decade [5]. It damages newly developed leaves and young twigs of Eucalyptus spp., and forms typical galls in the form of distinct swellings on leaf midribs, petioles and young twigs, in both plantations and nursery stock. Heavy galling causes deformity of leaf shape, abnormality of sapling growth, reduction of wood yield [32], and a subsequent decrease in farming revenue.

Leptocybe invasa is a thelytokous species $[32,36,54]$ in which the mothers produce only diploid daughters from unfertilized haploid eggs and offspring are genetically identical to 
their mothers $[32,50]$. The female $L$. invasa is also a proovigenic species $[43,53]$. Studies on the L. invasa population in Italy, Tunisia and Argentina found only females, indicating that $L$. invasa reproduced by thelytokous parthenogenesis $[1,9,32,48]$. Afterwards, males were reported in Turkey [16], India [22], China [6], Taiwan [47] and Thailand [43]. Male $L$. invasa were recorded at $0.5 \%$ of the Turkish population [16] and up to $18-48 \%$ of the Chinese one [30]. The morphology of $L$. invasa was not different in the Turkish and Chinese population [36].

Rickettsia infection (an endosymbiotic bacterium) in the reproductive tissue induced thelytoky in L. invasa [36]. However, the presence of males in a thelytokous population of L. invasa, where Rickettsia was involved in the manipulation of the reproduction, could be due to the interaction between the host genotype and its own Rickettsia [24, 36, 50]. On the other hand, the density of Rickettsia could decrease at high temperatures, which caused the presence of males in the thelytokous species [3, 17, 18, 49]. Moreover, studies based on molecular and phylogenetic analyses of $L$. invasa, genetic differences at the strain level of Rickettsia symbionts, and sex ratio differences suggest separation of Turkish and Chinese lineages, which can therefore be treated as putative species [36]. Besides sex ratio, other biological features of $L$. invasa have been reported $[8,43,55]$. The results varied considerably with methodologies and experimental condition settings. Outbreaks of $L$. invasa have also been associated with its reproductive biology [11, 54].

The management methods used to control L. invasa include chemical control [26], breeding and selection of resistant planting stock [12, 29, 40], and biological control [10, 28, 35]. Chemical control is not widely accepted due to its varying success, negative effects on biodiversity, and environmental pollution [52]. As E. camaldulensis has a wide range of resistance to gall inducers [29], breeding and selection of resistant planting stock are carried out against $L$. invasa. Thai researchers were able to produce various eucalyptus clones [34]. The reasons for clone production were mainly to increase wood yield and resistance to eucalyptus pests. In fact, the clones vary in degrees of damage caused by L. invasa, and their variations in biomass were observed in different planting sites [2]. The collenchyma cell wall thickness of abaxial and adaxial ground tissues of the midrib and petiole indicate L. invasa resistance [2]. It also was noted that a tolerant trait from a mother clone may not be transferred to the new generation. A group of Thai researchers were able to produce a eucalyptus hybrid (E. camaldulensis Dehnh. x E. pellita F. Muell.) that tolerated this pest. Further attempts are being made to solve the problem of a specific planting site for this hybrid [40].

Biological control is an attractive alternative to other control methods, due to its ecological and economic benefits [7]. It is an important tool to minimize the adverse effect of $L$. invasa and limit the populations of gall inducers [14, 28]. Some parasitoids of $L$. invasa have been reported in many countries $[13-15,25,28,33,35,38,39,41,51,52]$, in which the parasitism level was different. The local Megastigmus thitipornae Dogănlar \& Hassan (Hymenoptera: Torymidae) had less parasitic capacity to control L. invasa in Thailand [42]. The authors of this study observed a parasitoid of L. invasa in eucalyptus plantations. The specimens were sent to Dr. John La Salle,
CSIRO, Australia, in November 2014, and he confirmed their identity as Quadrastichus mendeli Kim \& La Salle (Hymenoptera: Eulophidae), which is a parasitoid native of Australia. From preliminary population samplings by the authors, the spread and naturally established adult of $Q$. mendeli in eucalyptus plantations was notable in some provinces of Thailand.

Quadrastichus mendeli is a uniparental species in which the males are unknown [28, 52]. The reproductive mode of Q. mendeli is thelytoky [21, 28]. A thelytokous population can grow more and faster than a sexual one $[31,45]$. The thelytoky of $Q$. mendeli is due to Rickettsia infection [21]. The spread and natural establishment of $Q$. mendeli $[35,52]$ and its biological aspects such as longevity, fecundity, and development of $Q$. mendeli have been reported [28]. In general, a shorter lifespan of the parasitoid in comparison with that of its host is a desirable characteristic in successful biological control, as it can produce its progeny at a faster rate than the host, and parasitize the host population in a shorter time [19, 20,44].

In order to reduce the use of chemicals in the agroecosystem, the study on potentiality of $Q$. mendeli to minimize damage caused by $L$. invasa should be carried out in Thailand, particularly on a susceptible clone of $E$. camaldulensis. Furthermore, the environmental conditions in the tropical region are significantly different from other areas. This makes the study worthwhile, particularly since $Q$. mendeli may be an effective control agent for L. invasa in this country. This research assessed the biological traits of $Q$. mendeli. Biological features studied include longevity and survival pattern, potential and realized fecundity, and developmental time. The results obtained from this research could be used to assess the potentiality of $Q$. mendeli in order to minimize the damage caused by $L$. invasa in Thailand.

\section{Materials and methods}

\section{Assessment of longevity and survival pattern of $Q$. mendeli}

Adult $Q$. mendeli ( $<6$ hour-old after emergence) were sampled from leaf galls collected from an area planted with a susceptible E. camaldulensis clone (CT 76 clone), put in a vial (4.5 $\mathrm{cm}$ in diameter, $8 \mathrm{~cm}$ high), and fed with three different feeding treatments: no diet, pure water, and honey solution (honey:water $=1: 1$ ). Each treatment comprised five replicates and ten parasitoids per replicate. Diets of pure water and honey solution were dropped onto small cotton balls and refreshed daily until all of the wasps had died. Each vial was covered with fine mesh to provide ventilation. The number of dead and living parasitoids in each treatment was counted daily to determine the longevity and survival pattern under each diet regime. The experiments were maintained in the laboratory at a temperature of $27 \pm 1{ }^{\circ} \mathrm{C}$ and $75 \pm 5 \%$ relative humidity (RH). This temperature represented the average for outdoors during the period of this study. All experiments carried out in this research were also maintained at this temperature. The results from this temperature could provide more realistic data for Thailand. The longevity of $Q$. mendeli was analyzed via an $F$-test, using a statistical software program (SPSS for Windows version 11.5). Tukey's honestly significant difference test was used to compare the 
means of treatment. A difference of means was considered significant at a level of $p<0.05$.

\section{Determination of $Q$. mendeli fecundity}

\section{Potential fecundity}

Potential fecundity (egg load) is expressed as the maximum number of mature eggs in the ovary that can be laid potentially by an adult female parasitoid at the time of investigation. The eggs can be counted directly by dissecting the ovary of the adult. Newly emerged female parasitoids were separated into seven vials, each covered in fine mesh, with ten parasitoids per vial. They were fed with honey solution dropped onto small cotton balls in the vials. The females were sacrificed by freezing at ages of $<6,6,12,24,48,72$, and $96 \mathrm{~h}$ after emergence. Their ovaries were dissected in saline solution under a stereoscope. The number of mature eggs in each female was determined. The effect of age on the mean egg load was analyzed via the $F$-test. The length of the female hind tibia of all ages was measured and used as a substitute for female size [27]. The relationship between the number of mature eggs (egg load) and size (hind tibia length) was analyzed via simple linear regression, using a statistical software program (SPSS for Windows, version 11.5).

\section{Realized fecundity}

This term denotes the numbers of progeny produced by female wasps that survive to emerge as adult [4]. In general, fecundity is determined by counting the real number of eggs deposited on a host per day until the female dies, and then calculating the total number of eggs laid on the host over the female's life-time. However, Q. mendeli eggs were difficult to detect and count because they were laid inside leaf-galls of their hosts. Thus, this research determined the realized fecundity of $Q$. mendeli by counting the total number of emerging progeny that survived to adulthood, and expressing in terms of progeny per female $[23,46]$. This study was divided into two parts as described below.

Part 1 - determination of appropriate gall stage for parasitism: the eucalyptus saplings were planted in plastic pots and kept in fine mesh cages to prevent gall wasps from entering from outside. Twenty shoots of $E$. camaldulensis saplings were sampled. Each shoot was enveloped in fine mesh, with adult L. invasa females ( $<6$ hour-old after emergence) being released inside the envelope for $24 \mathrm{~h}$, using three females per shoot. The development of $L$. invasa in leaf galls was divided into four stages (egg, young larva, mature larva, and pupa) and five shoots were used in each stage. The stages of L. invasa development were assessed in terms of number of days after L. invasa oviposition; egg (11 days), young larva (18 days), mature larva (30 days), and pupa (38 days) [43].

When the development of L. invasa reached each stage, the galled shoots were enveloped in fine mesh again. A single Q. mendeli (24 hour-old) was fed with honey solution before introduction to and placement on each infested shoot for $24 \mathrm{~h}$. The fine mesh was removed from the shoot after the exposure. The galls of each shoot were cut and put into a vial
Table 1. Longevity of female Quadrastichus mendeli fed on different diets.

\begin{tabular}{lc}
\hline Diet & Longevity (days) \\
\hline No diet & $1.5 \pm 0.5^{\mathrm{a}}$ \\
Pure water & $1.5 \pm 0.5^{\mathrm{a}}$ \\
Honey solution & $4.80 \pm 0.65^{\mathrm{b}}$ \\
\hline
\end{tabular}

Values are shown as mean $\pm S E ; F=22.261, d f=2, p<0.01$. Means followed by the same superscript letter within each column are not significantly different (Tukey's honestly significant difference test, $p<0.05)$.

(4.5 $\mathrm{cm}$ in diameter, $8 \mathrm{~cm}$ high) before the emergence of L. invasa and $Q$. mendeli. The number of emerging wasps from the galls per shoot was determined. The appropriate gall stage for the parasitism of $Q$. mendeli was assessed. The experiments were carried out in ventilated cages $(1.60 \mathrm{~m} \times 1.60 \mathrm{~m} \times 2.0 \mathrm{~m})$ covered with fine mesh and maintained in the laboratory at a temperature of $27 \pm 1{ }^{\circ} \mathrm{C}$.

Part 2 - assessment of realized fecundity: 150 shoots were sampled from E. camaldulensis saplings in pots. Each shoot was wrapped with fine mesh. The adult female $L$. invasa ( $<6$ hour-old after emergence) were released inside the envelope for $24 \mathrm{~h}$, using three females per shoot. As the galls reached the appropriate stage for parasitism (mature larva; 30 days from the results of Part 1), one $Q$. mendeli (24 hour-old), which had been fed with honey solution prior to use, was introduced to each infested shoot for $24 \mathrm{~h}$. The parasitoid was transferred to a newly infested shoot on the following day and left for $24 \mathrm{~h}$. This procedure was conducted daily until the parasitoid had died. The parasitoid was fed during the experiments with honey solution on small cotton balls hanging on the shoots. These studies were conducted in a ventilated greenhouse covered with fine mesh. The galls of each shoot were cut and put into a vial before the emergence of $L$. invasa and $Q$. mendeli. The numbers of emerging $L$. invasa and $Q$. mendeli were counted daily until no wasps emerged, and the realized fecundity of $Q$. mendeli was then assessed.

\section{Study on the developmental time of $Q$. mendeli}

Eucalyptus camaldulensis saplings were planted in plastic pots and kept in fine mesh cages to prevent gall wasps entering from outside. Twenty shoots of $E$. camaldulensis were sampled. Each shoot was enveloped with fine mesh and adult female L. invasa ( $<6$ hour-old after emergence), which had been fed with honey solution prior to use, were released inside the envelope for $24 \mathrm{~h}$, using five females per shoot. After reaching the appropriate gall stage for parasitism, one $Q$. mendeli (24 hour-old), which had been fed with honey solution prior to use, was introduced to each infested shoot for $24 \mathrm{~h}$. This study was conducted in ventilated cages $(1.60 \mathrm{~m} \times 1.60 \mathrm{~m} \times$ $2.0 \mathrm{~m}$ ) covered with fine mesh. After exposure, the fine mesh was removed from each shoot. Five leaves were collected daily. The galls were removed from the leaves and dissected daily until the parasitoid emergence was completed. The fresh larvae and pupae of the parasitoid were studied and photographed. 


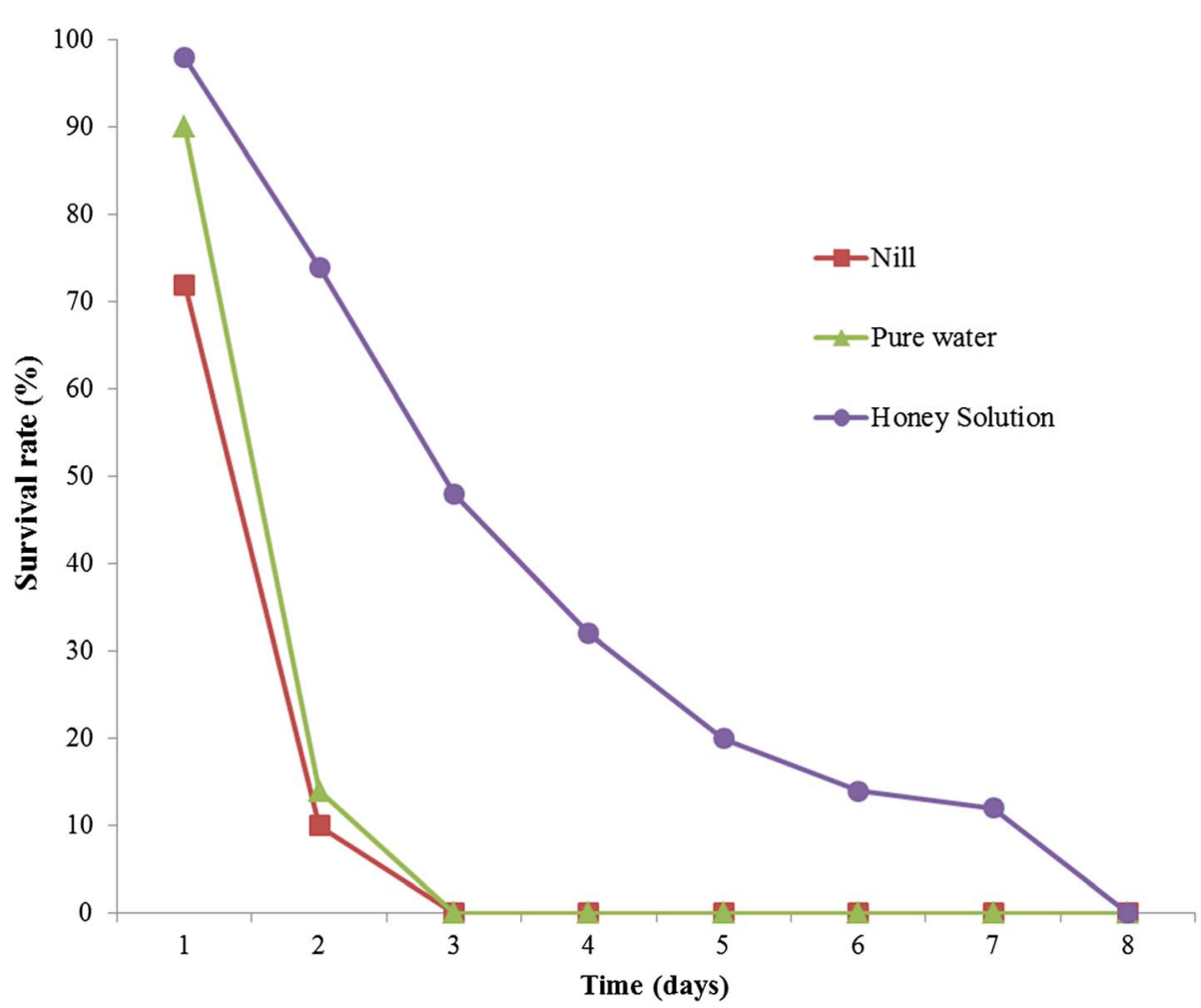

Figure 1. Survival patterns of female Quadrastichus mendeli fed on different diets.
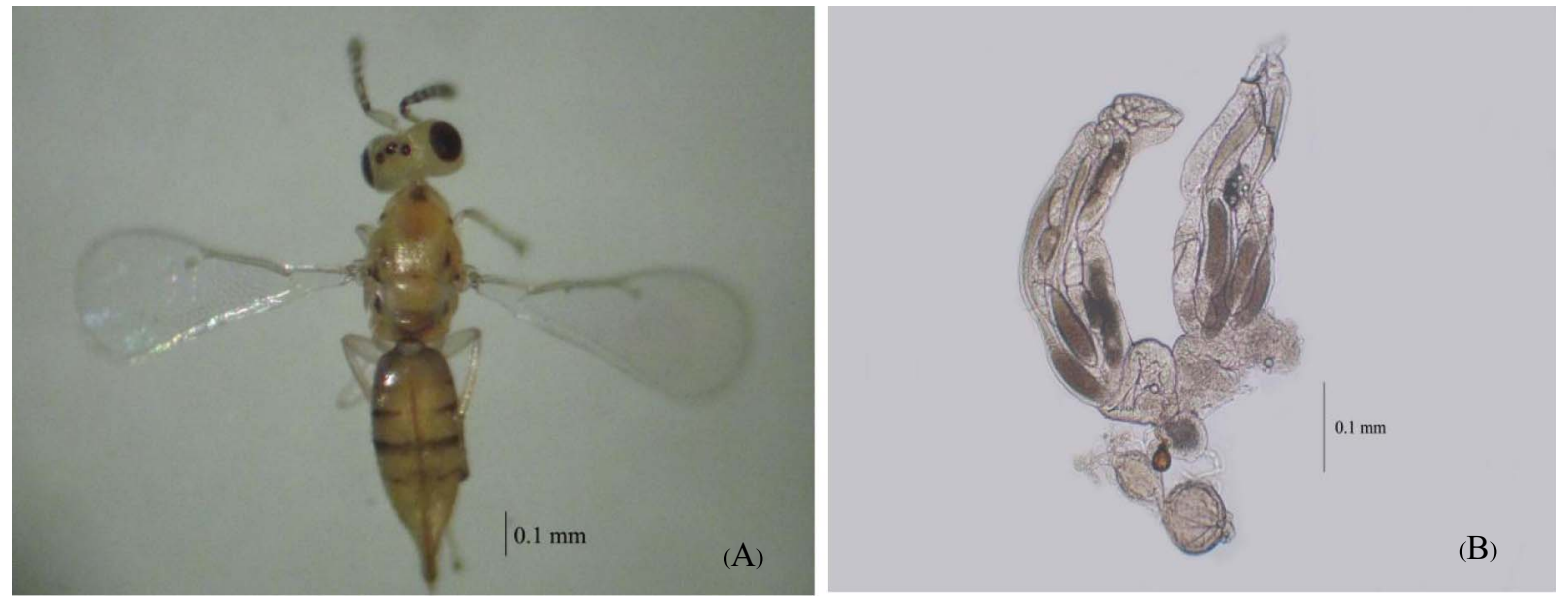

Figure 2. Quadrastichus mendeli; (A) adult female, and (B) mature eggs in ovary.

\section{Results}

\section{Longevity and survival pattern of $Q$. mendeli}

Diets had a highly significant effect on the mean longevity of $Q$. mendeli $(F=22.261, d f=2, p<0.01)$, and the details are shown in Table 1. Feeding $Q$. mendeli with honey solution prolonged its mean longevity to $4.80 \pm 0.65$ days, ranging from 4-7 days. This diet could extend longevity of this parasitoid to a greater extent than other diets, which maintained a lifespan of only 1.5 days. The study on survival pattern showed that adult female $Q$. mendeli fed with honey solution had a survival period ranging from 1-7 days, with an estimated 50\% survival period of 3 days (Fig. 1). Survival periods for females supplied with pure water and no-diet were shorter, ranging from 1-2 days, with an estimated $50 \%$ survival period of only 1 day.

\section{Fecundity of $Q$. mendeli}

\section{Potential fecundity}

Adult female $Q$. mendeli are shown in Figure 2A and mature eggs in ovary in Figure 2B. Dissection of the female $Q$. mendeli ovaries at $<6,6,12,24,48,72$, and $96 \mathrm{~h}$ after emergence revealed that all the eggs of newly emerged females 


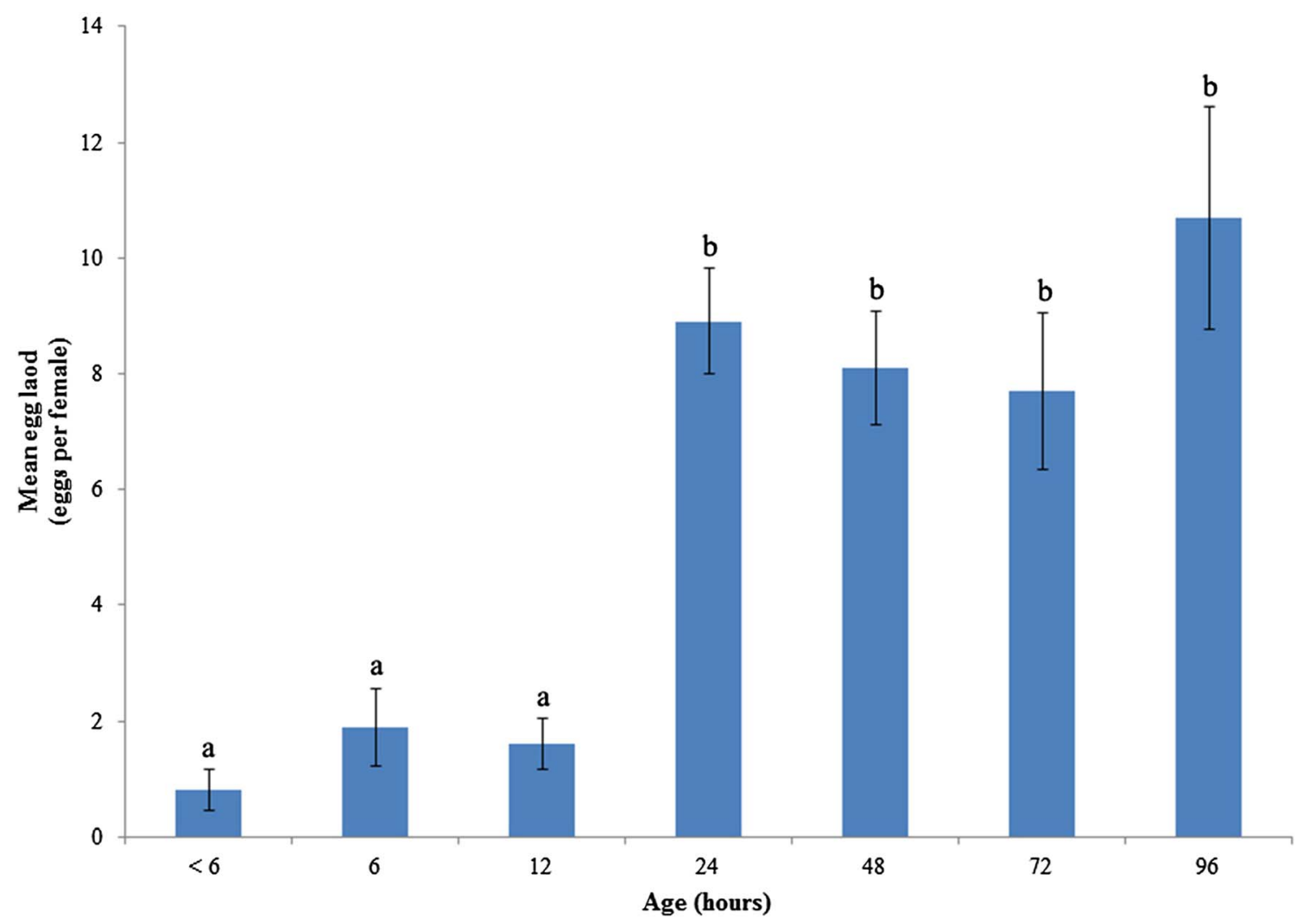

Figure 3. Effect of age on mean egg load of Quadrastichus mendeli $(F=14.48 ; d f=6 ; p<0.01)$. Vertical bars indicate standard error.

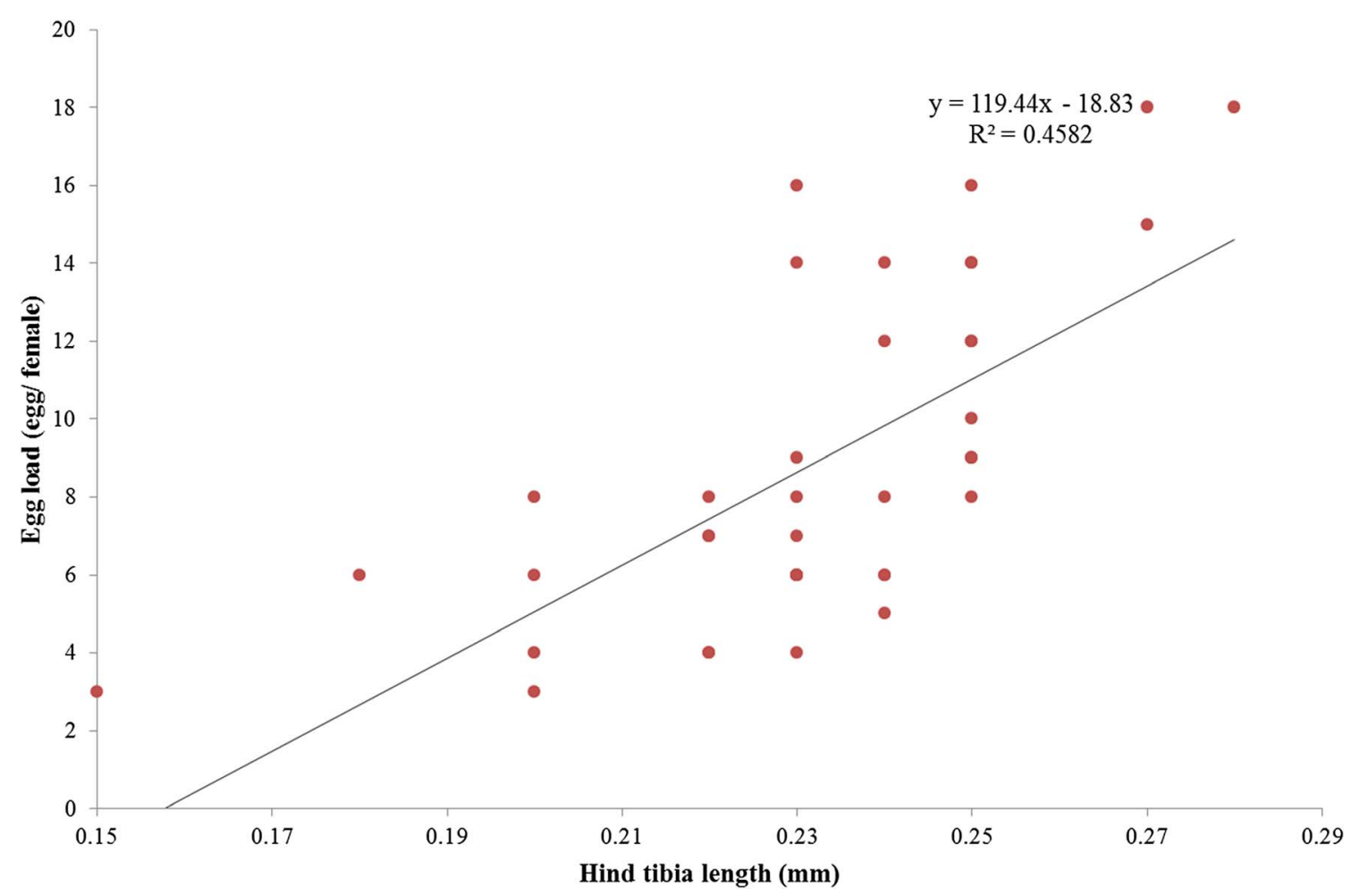

Figure 4. Relationship between predicted egg load $(y)$ and size $(x)$ of Quadrastichus mendeli $(n=40, p<0.01)$. 


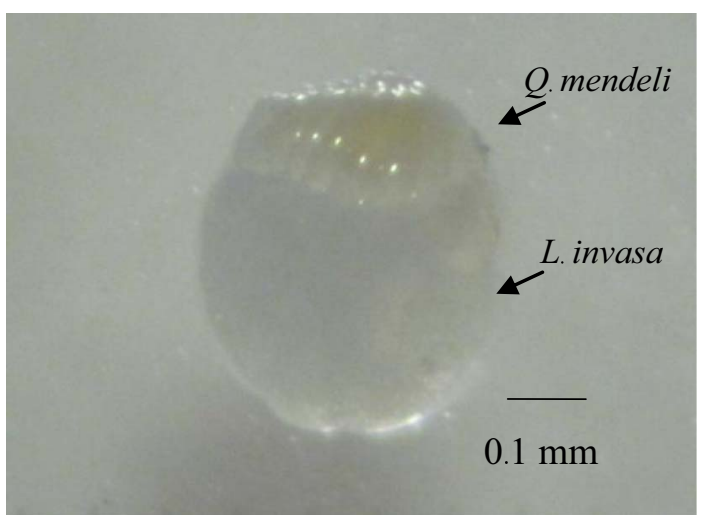

Figure 5. Larva of Quadrastichus mendeli developing on that of Leptocybe invasa.

( $<6$ hour-old) were immature. However, some were mature when the female had reached $6 \mathrm{~h}$ of age after emergence. Mature eggs are elongated with a long stalk of $0.4-0.6 \mathrm{~mm}$ in length. The average potential fecundity (egg load) of females, aged $<6,6,12,24,48,72$, and $96 \mathrm{~h}$ was $0.8 \pm 0.36,1.9 \pm 0.67$, $1.6 \pm 0.45,8.9 \pm 0.91,8.1 \pm 0.97,7.7 \pm 1.36$, and $10.7 \pm 1.92$ eggs per female, respectively. The mean egg load in all ages was $8.85 \pm 0.67$ eggs per female, ranging from 3-18 eggs per female. The effect of female age (hour after emergence) on the mean egg load of $Q$. mendeli is shown in Figure 3. One-way analysis of variance showed that age had a highly significant effect on the mean egg load of this parasitoid $(F=14.48 ; d f=6 ; p<0.01)$.

By using the length of the hind tibia as a substitute for female size, the average size of female $Q$. mendeli in all ages was $0.23 \pm 0.003 \mathrm{~mm}$, ranging from 0.15 to $0.28 \mathrm{~mm}$. The results showed a positive relationship between egg load $(y)$ and size $(x)\left(y=119.44 x-18.83, R^{2}=0.458, n=40\right.$, $p<0.01$ ) (Fig. 4). The coefficient of regression $\left(R^{2}\right)$ indicated that size influenced egg loads (number of mature eggs) at the level of $45.80 \%$.

\section{Realized fecundity}

Determination of the appropriate gall stage for the parasitism of $Q$. mendeli showed that the females parasitized both young and mature larvae of $L$. invasa (12-33 days after L. invasa oviposition). This result revealed that the mean realized fecundity of female $Q$. mendeli throughout her life span was $2.47 \pm 0.30$ progenies per female, ranging from $1-7$ progenies per female.

\section{Developmental time of $Q$. mendeli}

The single egg of $Q$. mendeli developed as a solitary ectoparasitoid and completed its development outside the host body (Fig. 5). The mean developmental time of $Q$. mendeli, from egg to adult stage, was $27.06 \pm 1.19$ days, ranging from 22 to 40 days. The development of egg, young larval, mature

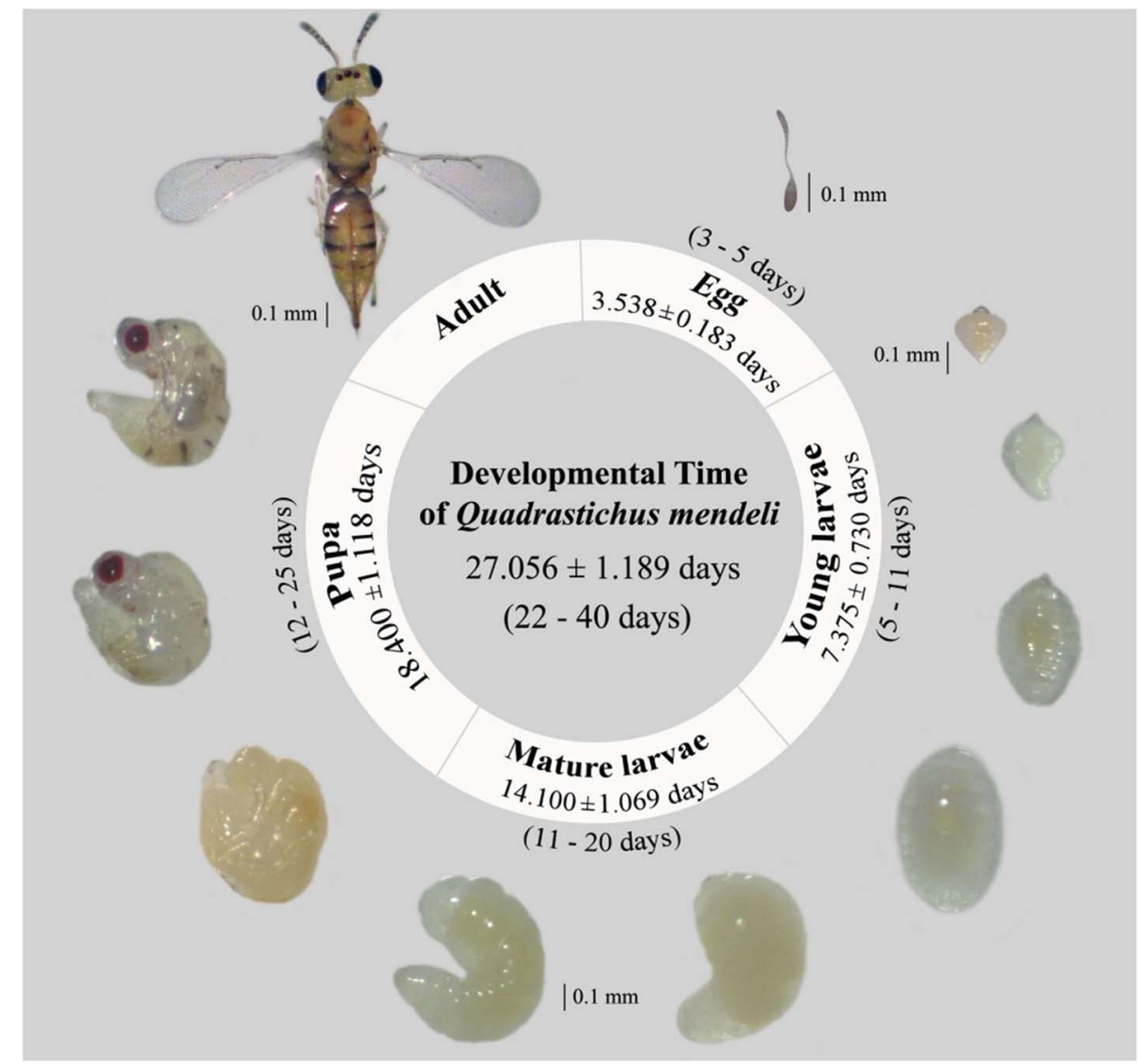

Figure 6. Development of Quadrastichus mendeli. Values are shown as mean $\pm S E$; range is shown in parentheses $=($ minimum-maximum $)$. 
larval, and pupal stage took $3.54 \pm 0.18,7.38 \pm 0.73$, $14.10 \pm 1.07$, and $18.40 \pm 1.12$ days, respectively. Young larvae are droplet or oval-shaped, while mature larvae are C-shaped (Fig. 6).

\section{Discussion}

Leptocybe invasa is a thelytokous species [32, 36, 54]. Males of $L$. invasa have however been recorded in many countries. In Thailand, the mean sex ratio between the female and male offspring of $L$. invasa in laboratory test was $1.97: 1$, but the males were non-functional [43]. The presence of males was directly related to infection of Rickettsia in its reproductive tissues $[24,36,50]$, and led to a difference in the L. invasa sex ratio. Regarding the sex distortion of offspring, the $L$. invasa population in Thailand belonged to the Chinese lineage. However, data from a mitochondrial study indicated that the L. invasa populations in Thailand were a Western and Chinese lineage combination [11].

Quadrastichus mendeli is a uniparental species [28, 52]. It is a solitary ectoparasitoid wasp. The reproductive mode of Q. mendeli is thelytoky $[21,28]$ which was manipulated by infection of Rickettsia [21]. The biological traits of $Q$. mendeli at $27 \pm 1{ }^{\circ} \mathrm{C}$ in this study showed that some findings differed from those at $25^{\circ} \mathrm{C}$ in Israel [28]. In particular, the estimated $50 \%$ survival rate and the mean developmental time of Q. mendeli in this study (3 days and 27.06 days) were shorter than those in Israel (6 days and 30 days) [28]. The findings varied considerably, probably due to differences in methodologies and experimental condition settings. Temperature is an important environmental factor affecting growth and development of insects [55].

The longevity, potential and realized fecundity, and developmental time of $Q$. mendeli in this study were lower than those of L. invasa [43]. Comparing the mean developmental time of $Q$. mendeli (27.06 days) with that of $L$. invasa (45.96 days) [43], it was found that the short life cycle of $Q$. mendeli could be considered useful for this parasitoid, while other traits (i.e. longevity, fecundity) were not as favorable. With a short life cycle in a parasitoid, the species can produce its progeny at high numbers of generations per year and this plays a part in increasing the population growth rate $[19,20,44]$. However, the presence of males (although not functional) in L. invasa offspring may reduce the probability of parasitization of the next generation of $Q$. mendeli. There is evidence that the short lifespan of Closterocerus chamaeleon could play a role in the successful control of the eucalyptus gall wasp Ophelimus maskelli in Israel [38]. Thus, the uniparental nature of $Q$. mendeli and its shorter developmental time in comparison to its host can be considered good reasons for its potential use to minimize damage caused by L. invasa in Thailand.

Acknowledgements. The authors thank the Fast Growing Tree Association, Thailand, and related companies for providing financial support for this study. We are grateful to all our friends who helped in making this study possible. Special thanks are extended to Dr. John La Salle (CSIRO, Australia) for identifying the parasitoid specimens in November 2014. We also thank Mr. Robert Kimmins and two anonymous reviewers for their valuable comments on this manuscript.

\section{Conflict of interest}

The authors declare that they have no conflict of interest in relation to this paper.

\section{References}

1. Aquino DA, Botto EN, Loiácono MS, Pathauer P. 2011. Avispa de la agalla del Eucalipto, Leptocybe invasa Fisher \& La Salle (Hymenoptera: Eulophidae: Tetrastichinae), en Argentina. Revista de Investigaciones Agropecuarias, 37(2), 1-6.

2. Bhuchaisri W. 2012. Anatomy of eucalyptus leaf clones with emphasis on galler resistance. M.Sc. thesis. Bangkok, Thailand: Kasetsart University (in Thai with English abstract).

3. Bordenstein SR, Bordenstein SR. 2011. Temperature affects the tripartite interactions between bacteriophage WO, Wolbachia, and cytoplasmic incompatibility. PLoS One, 6(12), e0029106.

4. Bourchier RS, Smith SM, Song SJ. 1993. Host acceptance and parasitoid size as predictors of parasitoid quality for mass-reared Trichogramma minutum. Biological Control, 3(2), 135-139.

5. CABI. 2007. Leptocybe invasa Fisher \& La Salle. Distribution maps of pests, 698, 1-2.

6. Chen HY, Yao JM, Xu ZF. 2009. First description of the male of Leptocybe invasa Fisher \& La Salle (Hymenoptera: Eulophidae) from China. Journal of Environmental Entomology, 31, 285287.

7. De Clercq P, Mason PG, Babendreier D. 2011. Benefits and risks of exotic biological control agents. BioControl, 56(4), 681-698.

8. De Souza AR, Barbosa LR, Passo JRdS, Castro BMdCe, Zanuncio JC, Wilcken CF. 2018. Longevity and survival of Leptocybe invasa (Hymenoptera: Eulophidae), an invasive gall inducer on Eucalyptus, with different diets and temperatures. PeerJ, 6, e5265.

9. Dhahri S, Ben Jamaa M, Lo Verde G. 2010. First record of Leptocybe invasa and Ophelimus maskelli eucalyptus gall wasps in Tunisia. Tunisian Journal of Plant Protection, 5(2), 229-234.

10. Dittrich-Schröder G, Harney M, Neser S, Joffe T, Bush S, Hurley BP, Wingfield MJ, Slippers B. 2014. Biology and host preference of Selitrichodes neseri: a potential biological control agent of the eucalyptus gall wasp, Leptocybe invasa. Biological Control, 78, 33-41.

11. Dittrich-Schröder G, Hoareau TB, Hurley BP, Wingfield MJ, Lawson S, Nahrung HF, Slippers B. 2018. Population genetic analyses of complex global insect invasions in managed landscapes: a Leptocybe invasa (Hymenoptera) case study. Biological Invasions, 20, 2395-2420.

12. Dittrich-Schröder G, Wingfield MJ, Hurley BP, Slippers B. 2012. Diversity in Eucalyptus susceptibility to the gall forming wasp Leptocybe invasa. Agricultural and Forest Entomology, 14 (4), 419-427.

13. Doğanlar M. 2015. Diagnosis of Megastigmus spp. (Hymenoptera: Torymidae) reared from galls of Leptocybe invasa Fisher \& La Salle (Hymenoptera: Eulophidae) on Eucalyptus spp. (Myrtaceae) with description of a new species from South Africa. Entomofauna Zeitschrift für Entomologie, 36, 561-580.

14. Doğanlar M, Hassan E. 2010. Review of Australian species of Megastigmus (Hymenoptera: Torymidae) associated with Eucalyptus, with descriptions of new species. Australian Journal of Basic and Applied Sciences, 4(10), 5059-5120.

15. Doğanlar M, Zaché B, Wilcken CF. 2013. A new species of Megastigmus (Hymenoptera: Torymidae: Megastigminae) from Brazil. Florida Entomologist, 96(1), 196-199. 
16. Doğanlar O. 2005. Occurrence of Leptocybe invasa Fisher \& La Salle (Hymenoptera: Chalcidoidea) on Eucalyptus camaldulensis in Turkey, with a description of the male sex. Zoology in the Middle East, 35, 112-114.

17. Giorgini M. 2001. Induction of males in thelytokous populations of Encarsia meritoria and Encarsia protransvena: a systematic tool. BioControl, 46, 427-438.

18. Giorgini M. 2009. Influence of high temperature shock on the reproduction and development of the Wolbachia-induced parthenogenetic parasitoid wasp Encarsia formosa (Gahan). Acta Ecologica Sinica, 29, 4732-4737.

19. Godfray HCJ. 1994. Parasitoids: behavioral and evolutionary ecology. USA: Princeton University Press. p. 473.

20. Greathead DJ. 1986. Parasitoids in classical biological control, in Insect parasitoids, Waage JK, Greathead DJ, Editors. Academic Press: New York. p. 290-315.

21. Gualtieri L, Nugnes F, Nappo A, Gebiola M, Bernardo U. 2017. Life inside a gall: closeness does not favour horizontal transmission of Rickettsia between a gall wasp and its parasitoid. FEMS Microbiology Ecology, 93(7), 1-11.

22. Gupta A, Poorani J. 2009. Taxonomic studies on a collection of Chalcidoidea (Hymenoptera) from India with new distribution records. Journal of Threatened Taxa, 1(5), 300-304.

23. Hardy ICW, Griffiths NT, Godfray HCJ. 1992. Clutch size in a parasitoid wasp: a manipulation experiment. Journal of Animal Ecology, 61(1), 121-129.

24. Heimpel GE, de Boer JG. 2008. Sex determination in the Hymenoptera. Annual Review of Entomology, 53(1), 209-230.

25. Hernández CM, Aquino DA, Cuello EM, Andorno AV, Botto EN. 2015. First record of Megastigmus zebrinus Grissell (Hymenoptera: Torymidae) from Agentina associated with galls of Leptocybe invasa (Hymenoptera: Eulophidae). Revista de la Sociedad Entomológica Argentina, 74, 75-77.

26. Javaregowda PST, Patil RS. 2010. Evaluation of botanical and synthetic insecticides against eucalyptus gall wasp, Leptocybe invasa (Hymenoptera: Eulophidae). Karnataka Journal of Agricultural Sciences, 23, 200-202.

27. Jervis MA. 2005. Insects as natural enemies: a practical perspective. Netherlands: Springer. p. 748.

28. Kim IK, Mendel Z, Protasov A, Blumberg D, La Salle J. 2008. Taxonomy, biology and efficacy of two Australian parasitoids of the eucalyptus gall wasp, Leptocybe invasa Fisher \& La Salle (Hymenoptera: Eulophidae: Tetrastichinae). Zootaxa, 1910, $1-20$.

29. Kulkarni HD. 2010. Screening eucalyptus clones against Leptocybe invasa Fisher \& La Salle (Hymenoptera: Eulophidae). Karnataka Journal of Agricultural Sciences, 23(1), 87-90.

30. Liang Y, Jiyue LI, Xiujun W, Zuozhen LI. 2010. Observation on the male ratio of Leptocybe invasa adult. Forest Pest and Disease, 5, 21-22.

31. Maynard SJ. 1978. The evolution of sex. New York: Cambridge University Press. p. 236.

32. Mendel Z, Protasov A, Fisher N, La Salle J. 2004. Taxonomy and biology of Leptocybe invasa gen. \& sp.n. (Hymenoptera: Eulophidae), an invasive gall inducer on Eucalyptus. Australian Journal of Entomology, 43(2), 101-113.

33. Mendel Z, Protasov A, La Salle J, Blumberg D, Brand D, Branco M. 2017. Classical biological control of two eucalyptus gall wasps: main outcomes and conclusions. Biological Control, 105, 66-78.

34. Nambiar EKS, Harwood CE. 2014. Productivity of acacia and eucalypt plantations in South East Asia. 1. Bio-physical determinants of production: opportunities and challenges. International Forestry Review, 16(2), 225-248.
35. Nugnes F, Gebiola M, Gualtieri L, Russo E, Sasso R, Bernado U. 2016. When exotic biocontrol agents travel without passport: first record of Quadrastichus mendeli, parasitoid of the bluegum chalcid Leptocybe invasa, in Italy. Bulletin of Insectology, 69(1), 85-91.

36. Nugnes F, Gebiola M, Monti MM, Gualtieri L, Giorgini M, Wang J, Bernado U. 2015. Genetic diversity of the invasive gall wasp Leptocybe invasa (Hymenoptera: Eulophidae) and of its Rickettsia endosymbiont, and associated sex ratio differences. PLoS One, 10(5), e0124660.

37. Paine TD, Steinbauer MJ, Lawson SA. 2011. Native and exotic pests of Eucalyptus: a worldwide perspective. Annual Review of Entomology, 56, 181-201.

38. Protasov A, Blumberg D, Brand D, La Salle J, Mendel Z. 2007. Biological control of the eucalyptus gall wasp Ophelimus maskelli (Ashmead): Taxonomy and biology of the parasitoid species Closterocerus chamaeleon (Girault), with information on its establishment in Israel. Biological Control, 42(2), 196-206.

39. Protasov A, Dogănlar M, La Salle J, Mendel Z. 2008. Occurrence of two local Megastigmus species parasitic on the eucalyptus gall wasp Leptocybe invasa in Israel and Turkey. Phytoparasitica, 36(5), 449-459.

40. Roumunyamanee R. 2016. Effect of ammonium nitrate, agar concentration and relative humidity on hyperdricity reduction in in vitro shoot cultures of eucalyptus hybrid (Eucalyptus camaldulensis Dehn. x Eucalytus pellita F. Muell.). M.Sc. thesis. Bangkok, Thailand: Kasetsart University. (in Thai with English abstract).

41. Sangtongpraow B, Charernsom K. 2012. Longevity and developmental time of Aprostocetus sp. (Hymenoptera: Eulophidae), the local parasitoid of Leptocybe invasa Fisher \& La Salle (Hymenoptera: Eulophidae). International Symposium of BioPesticides and Ecotoxicological Network (2nd IS-BioPEN), 24-25 September, Maruay Garden Hotel, Bangkok, Thailand.

42. Sangtongpraow B, Charernsom K. 2013. Evaluation of parasitism capacity of Megastigmus thitipornae Dogănlar \& Hassan (Hymenoptera: Torymidae), the local parasitoid of eucalyptus gall wasp, Leptocybe invasa Fisher \& La Salle (Hymenoptera: Eulophidae). Kasetsart Journal (Natural Science), 47, 191-204.

43. Sangtongpraow B, Charernsom K, Siripatanadilok S. 2011. Longevity, fecundity and development time of eucalyptus gall wasp, Leptocybe invasa Fisher \& La Salle (Hymenoptera: Eulophidae) in Kanchanaburi province, Thailand. Thai Journal of Agricultural Science, 44(3), 155-163.

44. Sequeira R, Mackauer M. 1992. Nutritional ecology of an insect host parasitoid association: the pea aphid Aphidius ervi system. Ecology, 73(1), 183-189.

45. Silva IMMS, van Meer MMM, Roskam MM, Hoogenboom A, Gort G, Stouthamer R. 2000. Biological control potential of Wolbachia-infected versus uninfected wasps: laboratory and greenhouse evaluation of Trichogramma cordubensis and $T$. deion strains. Biocontrol Science and Technology, 10(3), 223-238.

46. Takagi M. 1985. The reproductive strategy on the gregarious parasitoid, Pteromolus puporum (Hymenoptera: Pteromalidae): 1. optimum number of eggs in a single host. Oecologia, 68(1), $1-6$.

47. Tung GS, La Salle J. 2010. Pest alert-a newly discovered invasion of gall-forming wasps, Leptocybe invasa (Fisher \& La Salle), on eucalyptus trees in Taiwan. Formosan Entomologist, $30,241-244$

48. Viggiani G, Laudonia S, Bernardo U. 2001. The increase of insect pests in Eucalyptus. Informatore Agrario, 58(12), 86-87.

49. Wang X, Xu HX, Liu SP, Tang JW, Zheng XS, Lu ZX. 2016. Influence of temperature on symbiotic bacterium composition in 
successive generation of egg parasitoid, Anagrus nilaparvate. Rice Science, 23(4), 203-210.

50. Weeks AR, Velten R, Stouthamer R. 2003. Incidence of a new sex-ratio-distorting endosymbiotic bacterium among arthropods. Proceedings of the Royal Society of London B: Biological Science, 270(1526), 1857-1865.

51. Yang $\mathrm{MM}$, Lin $\mathrm{YC}$, $\mathrm{Wu} \mathrm{YJ}$, Fisher $\mathrm{N}$, Saimanee $\mathrm{T}$, Sangtongpraow B, Zhu CD, Chiu WCH, La Salle J. 2014. Two new Aprostocetus species (Hymenoptera: Eulophidae: Tetrastichinae), fortuitous parasitoids of invasive eulophid gall inducers (Tetrastichinae) on Eucalyptus and Erythrina. Zootaxa, 3846(2), 261-272.

52. Zheng XL, Huang ZY, Dong D, Guo CH, Li J, Yang ZD, Yang $\mathrm{XH}, \mathrm{Lu}$ W. 2016. Parasitoids of the eucalyptus gall wasp
Leptocybe invasa (Hymenoptera: Eulophidae) in China. Parasite, 23, 58.

53. Zheng XL, Huang ZY, Li J, Yang ZD, Yang XH, Lu W. 2018. Reproductive biology of Leptocybe invasa Fisher \& La Salle (Hymenoptera: Eulophidae). Neotropical Entomology, 47(1), 19-25.

54. Zheng XL, Yang ZD, Li J, Xian ZH, Yang J, Liu JY, Su S, Wang $\mathrm{XL}, \mathrm{Lu}$ W. 2014. Rapid identification of both sexes of Leptocybe invasa Fisher \& La Salle (Hymenoptera: Eulophidae: Tetrastichinae): a morphological perspective. African Entomology, 22, 643-650.

55. Zhu FL, Ren SX, Qiu BL, Wu JH. 2014. Effect of temperature on life table parameters of Leptocybe invasa (Hymenoptera: Eulophidae). Austral Entomology, 54(1), 71-78.

Cite this article as: Sangtongpraow B \& Charernsom K. 2019. Biological traits of Quadrastichus mendeli (Hymenoptera, Eulophidae), parasitoid of the eucalyptus gall wasp Leptocybe invasa (Hymenoptera, Eulophidae) in Thailand. Parasite 26, 8.

- PARASTE

An international open-access, peer-reviewed, online journal publishing high quality papers on all aspects of human and animal parasitology

Reviews, articles and short notes may be submitted. Fields include, but are not limited to: general, medical and veterinary parasitology; morphology, including ultrastructure; parasite systematics, including entomology, acarology, helminthology and protistology, and molecular analyses; molecular biology and biochemistry; immunology of parasitic diseases; host-parasite relationships; ecology and life history of parasites; epidemiology; therapeutics; new diagnostic tools.

All papers in Parasite are published in English. Manuscripts should have a broad interest and must not have been published or submitted elsewhere. No limit is imposed on the length of manuscripts.

Parasite (open-access) continues Parasite (print and online editions, 1994-2012) and Annales de Parasitologie Humaine et Comparée (1923-1993) and is the official journal of the Société Française de Parasitologie. 